\title{
Effect of elevation on photosynthesis of young mango (Mangifera indica L.) trees
}

\author{
T.T. WUBSHET,**, Z. WANG ${ }^{* * * *}$, J. YANG $^{*, * *}$, H. CHEN ${ }^{*}$, D.A. SCHAEFER ${ }^{*}$, S.D. GOLDBERG \\ P.E. MORTIMER ${ }^{*}$, P. LU**, and J. XU*,**,+ \\ Honghe Center for Mountain Futures, Kunming Institute of Botany, 650201 Kunming, Yunnan, China* \\ University of Chinese Academy of Sciences, 100049 Beijing, China** \\ Research Institute of Environment and Livelihoods, Charles Darwin University, NT 0810, Australia ${ }^{* * *}$
}

\begin{abstract}
Anticipating warming related to climate change, commercial mango plantations in China have been shifting from lower to higher elevations. Such a practice may expose mangoes to climatic conditions that could affect photosynthesis. Photosynthesis research on mango has previously examined mature plantations but exploring adequate functions before the time of fruit production is necessary for later crop success. Therefore, we established two main commercial mango cultivars, Tainong No. 1 and Jinhuang, at $450 \mathrm{~m}$ and 1,050 m and examined their photosynthetic performance. Our results showed that photosynthetic capacity parameters, including maximum photosynthetic rate, apparent quantum yield, maximum carboxylation rate, and photosynthetic electron transport rate, were significantly different between cultivars due to elevation and positively correlated with leaf nitrogen per area. Moreover, the seasonal gas exchange of the two cultivars showed variations due to elevation, particularly during the warmer seasons. Therefore, elevation affects the photosynthetic performance of these mango cultivars.
\end{abstract}

Keywords: cultivar; elevation; gas exchange; leaf nitrogen; mango; photosynthesis.

\section{Introduction}

Mango (Mangifera indica L.) is economically the most important tropical fruit tree (Morton 1987, FAO 2002, 2020), and China is the second largest mango-producing country in the world (FAO 2020). Currently, the country commercially grows more than ten mango cultivars, with Tainong No. 1 and Jinhuang being among the most common cultivars (Gao et al. 2019). Cultivar Tainong No. 1 (Haden $\times$ Irwin) was originally from Taiwan (Li et al. 2013a, Wang et al. 2015, Gao et al. 2019). Jinhuang (Nang Klang Wan $\times$ Keitt) is a polyembryonic cultivar and was originally from China (Luo et al. 2012, Wang et al. 2015). In the past two decades, commercial mango cultivation has been significantly expanding in the southern part of the country (Gao et al. 2011, 2019). Yunnan is one of the

\section{Highlights}

- Photosynthesis performance of mango is affected by elevation

- Cultivar Tainong No. 1 showed a higher photosynthesis performance at a higher elevation than Jinhuang

- Leaf nitrogen content has a strong positive relationship with photosynthesis capacity
Received 11 May 2021

Accepted 31 July 2021

Published online 2 September 2021

${ }^{+}$Corresponding author

e-mail: jxu@mail.kib.ac.cn

Abbreviations: AQY - apparent quantum yield; $\mathrm{CD}$ - cold-dry; $C_{\mathrm{i}}$ - intercellular $\mathrm{CO}_{2}$ partial pressure; $E$ - transpiration rate; $g_{\mathrm{s}}-$ stomatal conductance; $\mathrm{HD}$ - hot-dry; $J_{\max }$ - photosynthetic electron transport rate; LMA - leaf mas per area; $\mathrm{N}_{\mathrm{a}}$ - leaf nitrogen per area; $\mathrm{N}_{\mathrm{m}}$ - total nitrogen; $P_{\mathrm{N}}-$ net photosynthetic rate; $P_{\mathrm{Nmax}}-$ maximum photosynthetic rate; $P_{\mathrm{Nsat}}-$ light-saturated net photosynthetic rate; $\mathrm{RM}$ - recently matured leaf; $\mathrm{T}_{\text {leaf }}$ - leaf temperature; $V_{\max }$ - maximum carboxylation rate; VPD - vapor pressure deficit; WW - warm-wet. Acknowledgments: This work was generously supported by the Key Project from the Ministry of Sciences and Technology of China (2017YFC0505100) and Yunnan Provincial Science and Technology Department (202003AD150004).

Conflict of interest: The authors declare that they have no conflict of interest. 
provinces where this expansion has been occurring (Gao et al. 2019).

Anticipating warming related to climate change, mango plantations in the country have been consistently shifting from lower to higher elevations (Gao et al. 2011, 2019). However, establishing mango plantations at higher elevations could expose trees to climatic conditions that could affect photosynthesis and other related processes (Kingston-Smith et al. 1997, Jung et al. 1998). The effect of elevation on photosynthesis has been attributed to decreases in air partial pressure of $\mathrm{CO}_{2}$ as elevation increases (Sakata and Yokoi 2002, Vats and Kumar 2006), whereas its influences on stomatal conductance and transpiration are principally attributed to air temperature and vapor pressure deficit (VPD) (Gale 2004, Körner 2007, Motzer et al. 2017, Mujawamariya et al. 2018). However, studies on the effects of elevation on photosynthesis of tropical plants have not shown consistent trends (Friend et al. 1989, Cordell et al. 1999, Kao and Chang 2001, Zhang et al. 2005, Premoli and Brewer 2007, Wittich et al. 2012, Zhang and Yin 2012, Motzer et al. 2017, Mujawamariya et al. 2018).

Field and greenhouse studies on mango have revealed that temporary exposure to suboptimal temperatures caused inhibition of light-saturated photosynthetic assimilation (Allen et al. 2000, Allen and Ort 2001). Moreover, depending on the cultivar used, the degree of chilling could negatively impact photosynthesis (Whiley 1993, Allen and Ort 2001, Elsheery et al. 2007, 2008; Elsheery and Cao 2008, Damour et al. 2009, Normand et al. 2015). In addition, previous studies on mango concerning climatic factors largely focused on flowering and fruit production (Rajan 2011, Mathur et al. 2012, Normand et al. 2015). However, fruit production requires the survival of young trees under climatic conditions in production areas. Once mango plantations are established, only a few modifications can be implemented (Mathur et al. 2012). Mangoes also need at least four to five years before reaching optimum fruit production (Rajan 2011, Mathur et al. 2012). Therefore, investigating the photosynthetic performance of young mangoes in response to elevation can be a useful tool in predicting the suitability of given commercial mango cultivation at higher elevations. Consequently, this information will contribute to future planting decisions.

Moreover, studies on pre-fruiting mango trees primarily focus on the vegetative growth of plants (Whiley et al. 1989, Luvaha et al. 2008, Mng'omba et al. 2010, Pinto et al. 2018). A few studies of gas exchange at this stage have been conducted under controlled conditions (Allen et al. 2000, Allen and Ort 2001, Luvaha et al. 2007). Overall knowledge of mango field performance in the years before first fruiting is limited, potentially impacting the selection of suitable cultivars for a given site. In this study, we established plots with three-year-old mango cultivars Tainong No 1 and Jinhuang that exhibit locally high fruit production. We planted them at the same elevation currently used locally for mango production as well as at a higher elevation in anticipation of future plantation shifts. We examined photosynthetic performance before first fruiting. We hypothesized that the photosynthetic performance of mango cultivar Tainong No. 1 could be higher at the higher elevation $(1,050 \mathrm{~m})$, while the reverse could be true for the cultivar Jinhuang.

\section{Materials and methods}

Site description: The study was conducted on two northfacing plots established at elevations of 450 and 1,050 m above sea level (a.s.1.) located between longitude and latitude of $23^{\circ} 25.575^{\prime} \mathrm{N}, 102^{\circ} 15.845^{\prime} \mathrm{E}$ and $23.40839^{\circ} \mathrm{N}$, $102.24649^{\circ} \mathrm{E}$, respectively, Honghe County, Yunnan Province, China. Climatic data were retrieved from microclimate stations installed nearby (ca. $20 \mathrm{~m}$ ) to study plots at both elevations (Fig. 1).

Seedling growth conditions: All subsequent gas-exchange measurements were conducted on three-year-old, local mango cultivars, namely, Tainong No. 1 and Jinhuang. Trees were planted at 450 and $1,050 \mathrm{~m}$ a.s.1. with $5 \times 5-\mathrm{m}$ spacing on plots with similar soil properties. During the study period, trees were free of shade, irrigated, and fertilized according to local commercial farming practices.

Response of net photosynthesis to PPDF: Net photosynthetic rate $\left(P_{\mathrm{N}}\right)$ in response to PPFD was measured on two sun-exposed, recently matured leaves of three replicate trees $(n=2 \times 3)$ per cultivar per elevation. The photosynthesis system (Li-Cor 6400xt, USA) was adjusted at series of PPFD of 2,000; 1,800; 1,500; 1,200; 1,$000 ; 800,600,500,400,300,200,150,100,50$, and $0 \mu \mathrm{mol} \mathrm{m} \mathrm{m}^{-2} \mathrm{~s}^{-1}$, and at a constant $\mathrm{CO}_{2}$ concentration

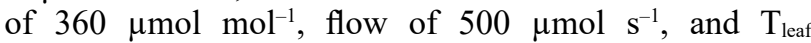
at $25^{\circ}$ C. $P_{\mathrm{N}}-$ PPFD response curve for each leaf was fitted according to Marshall and Biscoe (1980). Maximum photosynthetic rate $\left(P_{\mathrm{Nmax}}\right)$ and apparent quantum yield (AQY) were derived from the $P_{\mathrm{N}}-$ PPFD response curves. $P_{\mathrm{N}}-$ PPFD measurements were conducted from 8:30-11:30 h local time from 20-23 February 2019.

Response of net photosynthesis to internal $\mathrm{CO}_{2}$ concentration: Net photosynthetic rate $\left(P_{\mathrm{N}}\right)$ in response to internal $\mathrm{CO}_{2}\left(C_{\mathrm{i}}\right)$ at each elevation was measured on two sunexposed, recently matured leaves of three replicate trees $(n=2 \times 3)$ per cultivar per elevation. The photosynthesis system ( $\mathrm{Li}$-Cor 6400xt, USA) was adjusted at series of $\mathrm{CO}_{2}$ concentrations of $400,300,200,100,50,400,600$,

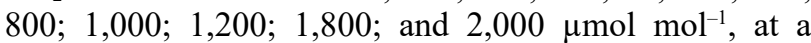
constant PPFD of $1,000 \mu \mathrm{mol} \mathrm{m}^{-2} \mathrm{~s}^{-1}$, flow of $300 \mu \mathrm{mol} \mathrm{s}^{-1}$, and $\mathrm{T}_{\text {leaf }}$ at $25^{\circ} \mathrm{C} . P_{\mathrm{N}}-C_{\mathrm{i}}$ response curve for each leaf was fitted according to Sharkey et al. (2007). Photosynthesis capacity parameters, including maximum carboxylation rate $\left(V_{\max }\right)$ and photosynthetic electron transport rate $\left(J_{\max }\right)$ were derived from the $P_{\mathrm{N}}-C_{\mathrm{i}}$ curves. $P_{\mathrm{N}}-C_{\mathrm{i}}$ measurements were conducted from 8:30-11:30 h local time from 24-27 February 2019.

Light-saturated gas exchange: The effect of elevation on seasonal light-saturated gas exchange was assessed at PPFD of $1,000 \mu \mathrm{mol} \mathrm{m} \mathrm{m}^{-2} \mathrm{~s}^{-1}$, and a $\mathrm{CO}_{2}$ concentration of 


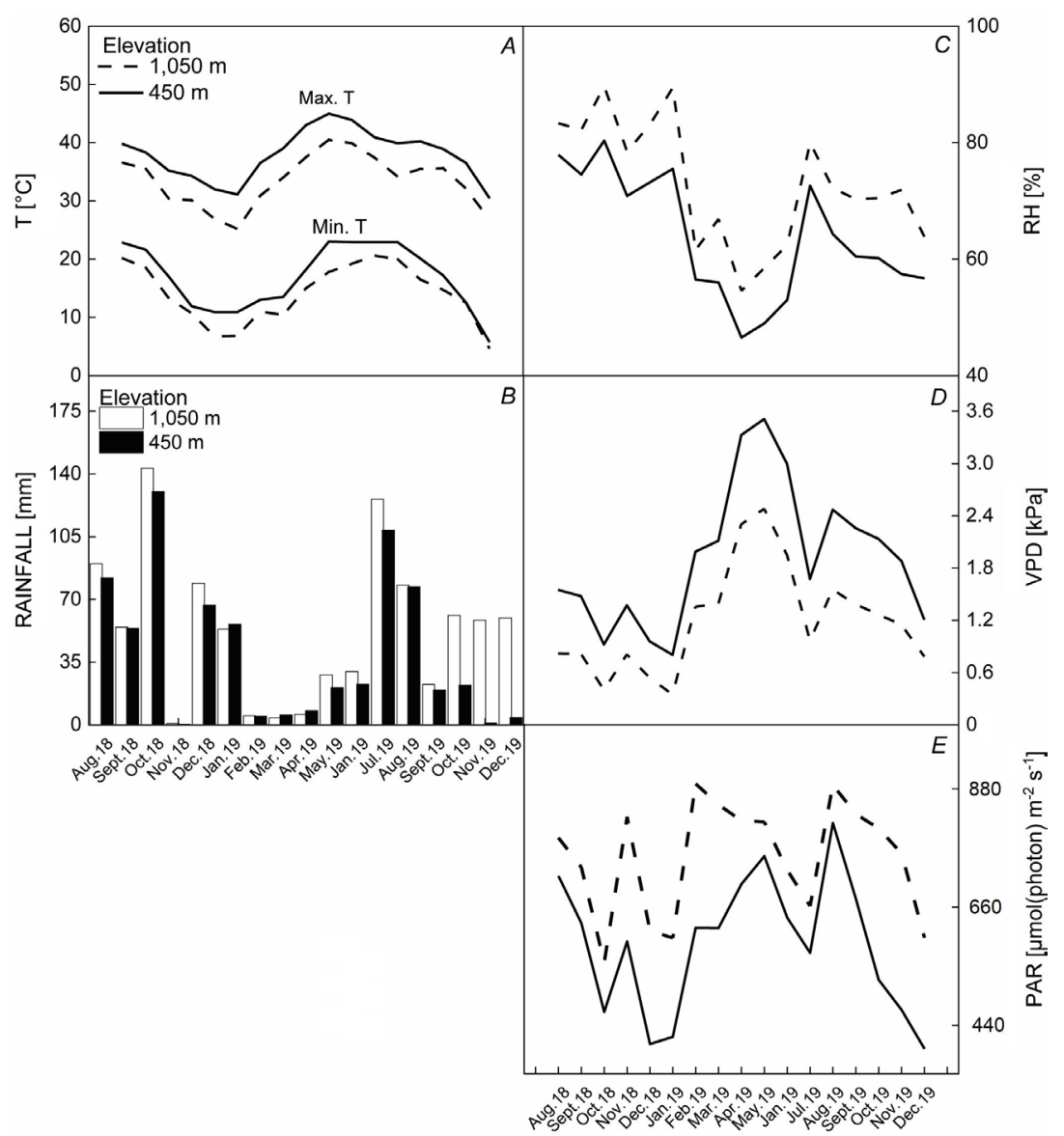

Fig. 1. Monthly maximum and minimum air temperature $(\mathrm{T})(A)$; mean monthly rainfall $(B)$; relative humidity $(\mathrm{RH})(C)$; vapor pressure deficit (VPD) $(D)$; and daytime photosynthetically active radiation (PAR) $(E)$ during the study period.
$360 \mu \mathrm{mol} \mathrm{mol}{ }^{-1}$. Measurements at the two elevations were carried out on four healthy, sun-exposed, recently matured (RM) leaves on four replicate trees $(n=4 \times 4)$ per cultivar per elevation, for a total of nine days to represent the hot-dry (HD) season (19-21 April 2019), warm-wet (WW) season (17-19 July 2019), and cold-dry (CD) season (15-17 December 2019). Gas-exchange measurements were carried out using a portable photosynthesis system ( $\mathrm{Li}$-Cor 6400xt, USA) between 8:00 to 11:30 h local time.

Leaf structural traits and nitrogen content: To examine the relationship between photosynthesis capacity with leaf nitrogen content, leaves used for $P_{\mathrm{N}}-$ PPFD and $P_{\mathrm{N}}-C_{\mathrm{i}}$ curves were harvested at the end of the experiment. Leaves were brought to the lab, and leaf area was measured using a leaf area meter ( $\mathrm{Li}$-Cor $3001 \mathrm{~A}$, USA). Then, dry mass was determined after leaves were oven-dried at $70^{\circ} \mathrm{C}$ for $48 \mathrm{~h}$, and LMA was calculated by dividing leaf dry mass by one-side leaf areas. Then, each leaf excluding the midrib was ground individually using mortar and pestle and sieved using No. 100 mesh. Total nitrogen $\left(\mathrm{N}_{\mathrm{m}}\right)$ was analyzed twice from 5-mg subsamples using (Vario MICRO cube, Germany). Nitrogen per unit area $\left(\mathrm{N}_{\mathrm{a}}\right)$ was calculated as total nitrogen $\left(\mathrm{N}_{\mathrm{m}}\right) \times$ leaf mass per unit area (LMA).

Data analysis: Data are presented as the mean $( \pm \mathrm{SE})$ of photosynthesis parameters. $T$-test was performed to test whether means were statistically significant using Statistix version 8.1 at $p \leq 0.001, p \leq 0.01$, and $p \leq 0.05$. Linear regression was used to detect the relationship between photosynthesis capacity parameters, including maximum carboxylation rate $\left(V_{\max }\right)$, photosynthetic electron transport rates $\left(J_{\max }\right)$, apparent quantum yield (AQY), and maximum photosynthetic rate $\left(P_{\mathrm{Nmax}}\right)$ derived from $P_{\mathrm{N}}$ response to light and $\mathrm{CO}_{2}$ curves to leaf nitrogen per area $\left(\mathrm{N}_{\mathrm{a}}\right)$. OriginPro 2021, version 9.8.0.2 was used for curve fitting and plotting.

\section{Results}

Elevation affected the maximum carboxylation rate $\left(V_{\max }\right)$ and photosynthetic electron transport rate $\left(J_{\max }\right)$ of both mango cultivars. Cultivar Tainong No. 1 showed significantly higher $V_{\max }$ and $J_{\max }$ compared to cultivar Jinhuang at $1,050 \mathrm{~m}$. However, at $450 \mathrm{~m}$, cultivar Jinhuang showed significantly higher $V_{\max }$ and $J_{\max }$ compared to cultivar Tainong No. 1 (Fig. 2).

Elevation influenced the apparent quantum yield (AQY) and maximum photosynthetic rate $\left(P_{\mathrm{Nmax}}\right)$ of both mango cultivars. Cultivar Tainong No. 1 showed significantly higher AQY and $P_{\mathrm{Nmax}}$ compared to cultivar Jinhuang at $1,050 \mathrm{~m}$. However, cultivar Jinhuang showed significantly higher AQY and $P_{\text {Nmax }}$ compared to cultivar Tainong No. 1 at $450 \mathrm{~m}$ (Fig. 3).

Photosynthesis capacity parameters of mango cultivars Tainong No. 1 and Jinhuang including apparent quantum 

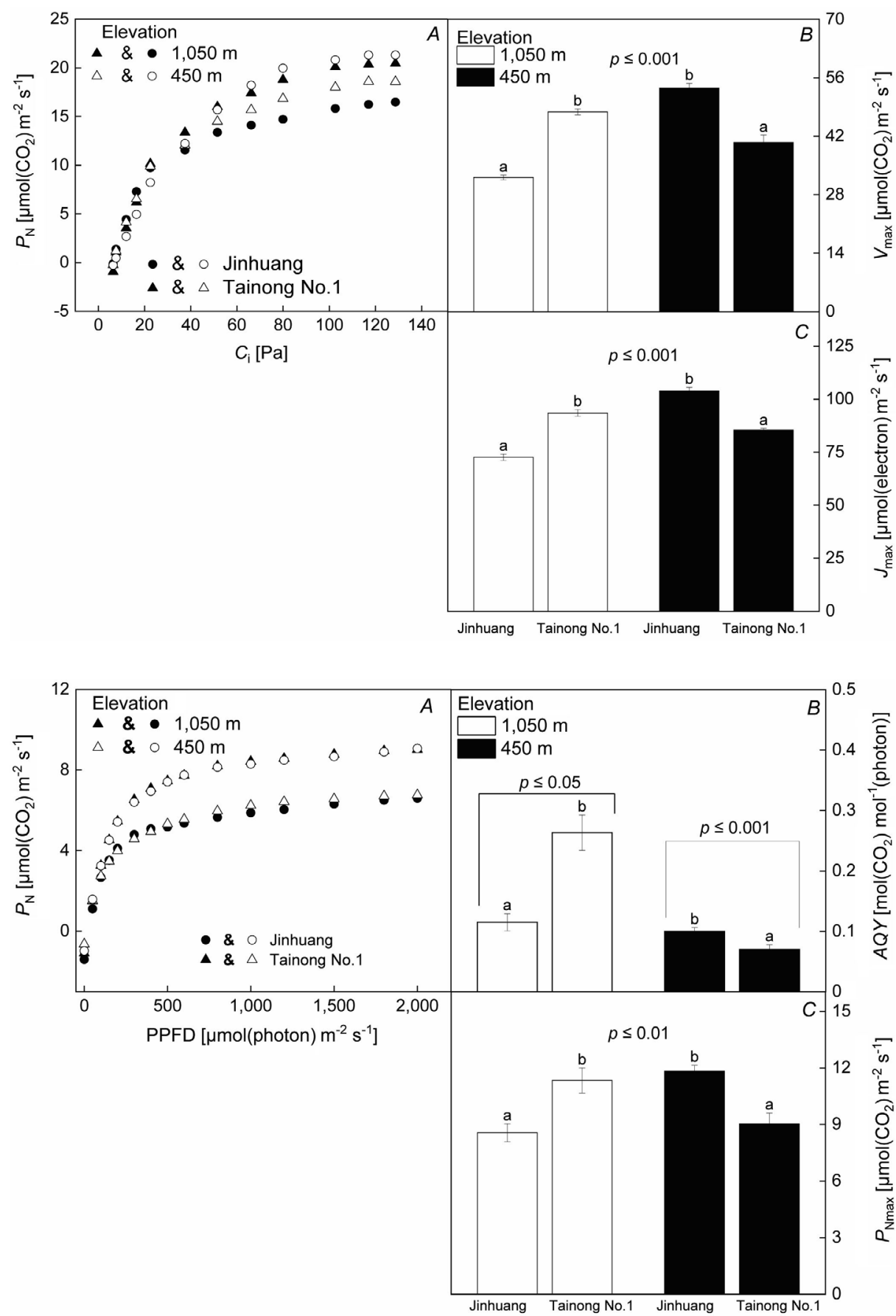

Fig. 2. Net photosynthetic rate $\left(P_{\mathrm{N}}\right)$ in response to internal $\mathrm{CO}_{2}$ partial pressure $\left(C_{\mathrm{i}}\right)\left(P_{\mathrm{N}}-C_{\mathrm{i}}\right)(A)$; maximum carboxylation rate $\left(V_{\max }\right)(B)$; and photosynthetic electron transport rate $\left(J_{\max }\right)(C)$ of mango cultivars Tainong No. 1 and Jinhuang grown at $1,050 \mathrm{~m}$ and $450 \mathrm{~m}$. Mean \pm SE. Different letters indicate the difference between means is statistically significant at $p \leq 0.001$.

Fig. 3. Net photosynthetic rate $\left(P_{\mathrm{N}}\right)$ in response to photosynthetic photon flux density (PPFD) $\left(P_{\mathrm{N}}-\mathrm{PPFD}\right)(A) ;$ apparentquantum yield (AQY) $(B)$; and maximum photosynthetic rate $\left(P_{\mathrm{Nmax}}\right)(C)$ of mango cultivars Tainong No. 1 and Jinhuang grown at $1,050 \mathrm{~m}$ and $450 \mathrm{~m}$. Mean \pm SE. Different letters indicate the statistically significant difference between means. yield (AQY) $\left(R^{2}=0.88,0.54,0.88,0.54\right)$ (Fig. 4A,B), maximum photosynthetic rate $\left(P_{\mathrm{Nmax}}\right)\left(R^{2}=0.86,0.86\right.$, $0.73,0.98$ ) (Fig. $4 C, D)$, maximum carboxylation rate $\left(V_{\max }\right)\left(R^{2}=0.91,0.8,0.81,0.84\right) \quad($ Fig. $4 E, F)$, and photosynthetic electron transport rate $\left(J_{\max }\right)\left(R^{2}=0.89\right.$, $0.84,0.88,0.95)($ Fig. $4 G, H)$ at both $1,050 \mathrm{~m}$ and $450 \mathrm{~m}$ showed positive linear relationships with leaf nitrogen per area $\left(\mathrm{N}_{\mathrm{a}}\right)$. Moreover, the total leaf nitrogen $\left(\mathrm{N}_{\mathrm{m}}\right)$ content of the cultivars Tainong No.1 and Jinhuang was significantly higher at $1,050 \mathrm{~m}$ compared to $450 \mathrm{~m}(p<0.001)$ (Fig. 5). However, no significant differences in $\mathrm{N}_{\mathrm{m}}$ were observed between the two cultivars.
Cultivar Tainong No. 1 showed significantly higher light-saturated photosynthesis $\left(P_{\text {Nsat }}\right)$ at $1,050 \mathrm{~m}$ compared to cultivar Jinhuang during hot-dry (HD) and warm-wet (WW) seasons. Conversely, Jinhuang showed significantly higher $P_{\mathrm{Nsat}}$ at $450 \mathrm{~m}$ during HD and WW seasons. However, neither cultivar showed statistically significant differences in $P_{\text {Nsat }}$ due to elevation and $P_{\text {Nsat }}$ was generally low during the cold-dry season (Fig. $6 \mathrm{~A}$ ). Moreover, intercellular $\mathrm{CO}_{2}$ $\left(C_{\mathrm{i}}\right)$ also showed no statistical difference between cultivars due to elevation except during the cold-dry season at $1,050 \mathrm{~m}$, where cultivar Tainong No. 1 showed lower $C_{\mathrm{i}}$ compared to Jinhuang. 


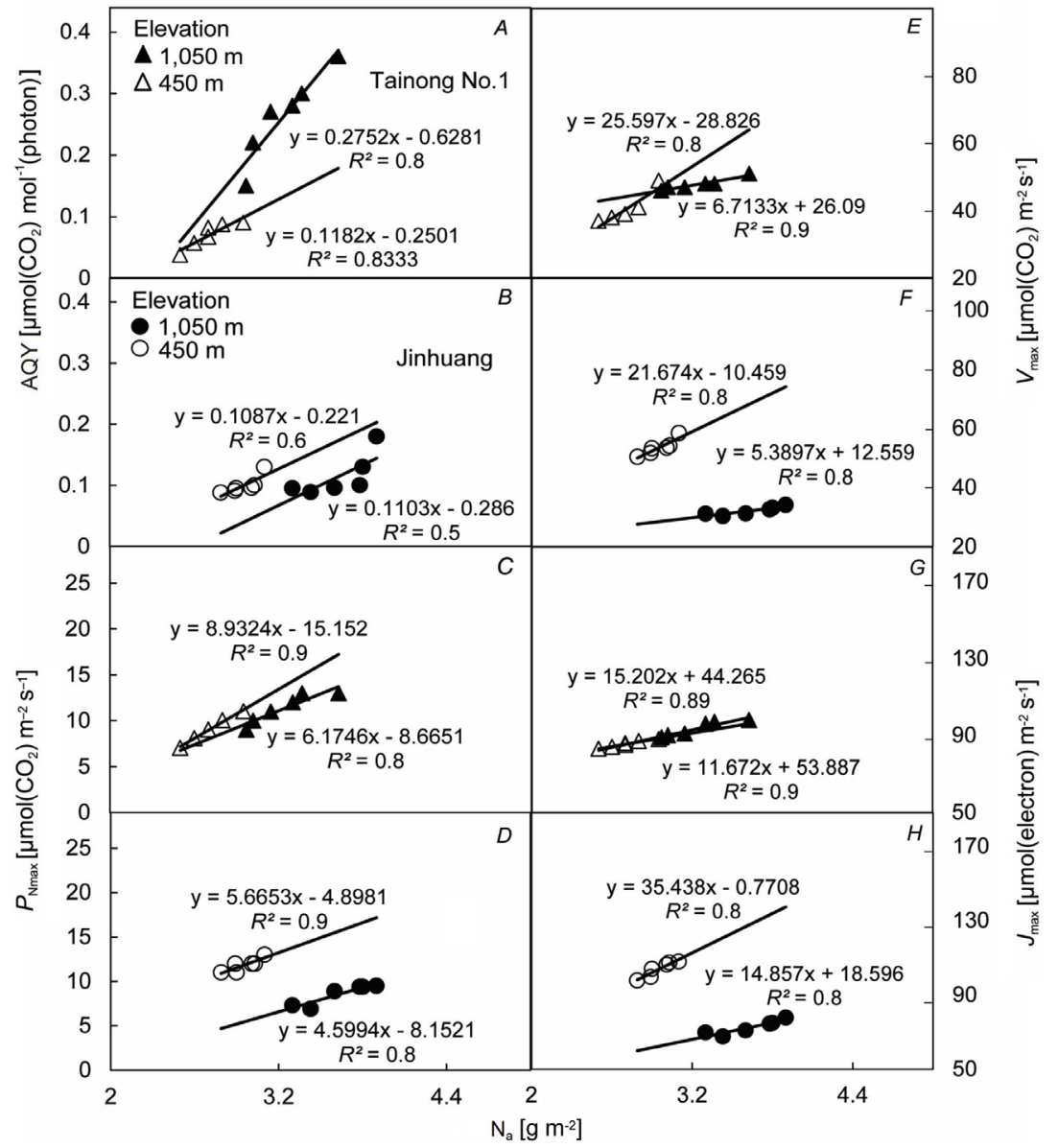

Fig. 4. Relationships of apparent quantum yield (AQY) $(A, B)$; maximum net photosynthetic rate $\left(P_{\mathrm{Nmax}}\right)(C, D)$; maximum carboxylation rate $\left(V_{\max }\right)(E, F)$; and photosynthetic electron transport rate $\left(J_{\max }\right)$ $(G, H)$ with leaf nitrogen per area $\left(\mathrm{N}_{\mathrm{a}}\right)$ of mango cultivars Tainong No. 1 and Jinhuang grown at $450 \mathrm{~m}$ and $1,050 \mathrm{~m}$.

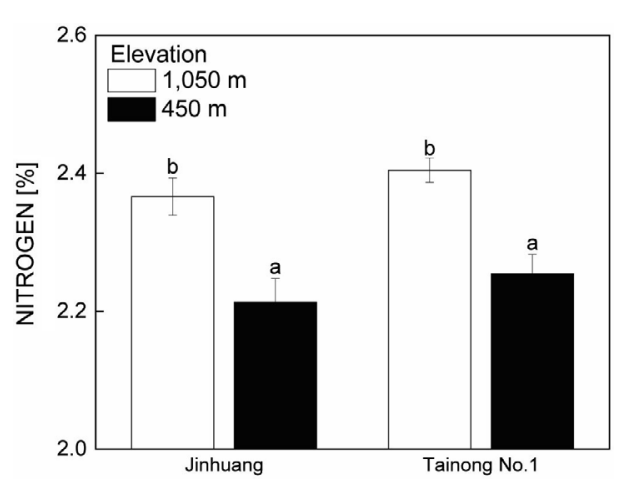

Fig. 5. Mean ( $\pm \mathrm{SE})$ total nitrogen content of leaves of mango cultivars Tainong No. 1 and Jinhuang grown at $450 \mathrm{~m}$ and $1,050 \mathrm{~m}$. Different letters indicate the difference between means is statistically significant at $p<0.001$.

Seasonal stomatal conductance $\left(g_{\mathrm{s}}\right)$ of Jinhuang and Tainong No. 1 showed significant difference due to elevation during the warm-wet season where Jinhuang showed higher $g_{\mathrm{s}}$ at $450 \mathrm{~m}$, while Tainong showed higher $g_{\mathrm{s}}$ at $1,050 \mathrm{~m}$. In addition, Tainong No. 1 showed significantly higher $g_{\mathrm{s}}$ compared to Jinhuang at $450 \mathrm{~m}$ during the hot-dry season. Furthermore, $g_{\mathrm{s}}$ was generally low during the cold-dry season while it was high during the hot-dry seasons at $450 \mathrm{~m}$; however, no significant difference between cultivars was observed due to elevation (Fig. 6C).

Furthermore, cultivar Tainong No. 1 showed a significantly higher transpiration rate $(E)$ compared to cultivar Jinhuang at 1,050 m during HD and WW seasons (Fig. 6D). The opposite was true at $450 \mathrm{~m}$. At $450 \mathrm{~m}$, cultivar Jinhuang showed significantly higher $E$ compared to cultivar Tainong No. 1 (Fig. 6D). Furthermore, both cultivars showed higher $E$ during the hot-dry season at both elevations and lower $E$ during the cold-dry season; nevertheless, there were no significant differences between cultivars due to elevation (Fig. 6D).

\section{Discussion}

Photosynthetic capacity parameters differed between mango cultivars studied depending on the elevation. Cultivar Tainong No. 1 had a higher $V_{\max }, J_{\max }$, AQY moles of $\mathrm{CO}_{2}$ fixed per mole photons (Ehleringer and Björkman 1977, Ehleringer and Pearcy 1983, Oberhuber et al. 1993), and $P_{\mathrm{Nmax}}$ at $1,050 \mathrm{~m}$, while this was true for Jinhuang at $450 \mathrm{~m}$. Similar studies on tropical plant species have also reported higher $V_{\max }, J_{\max }, \mathrm{AQY}$, and $P_{\text {Nmax }}$ at a higher elevation (Laisk et al. 1997, Shi et al. 2006, Fujimura et al. 2010, Liu et al. 2012, Dusenge et al. 2015). 


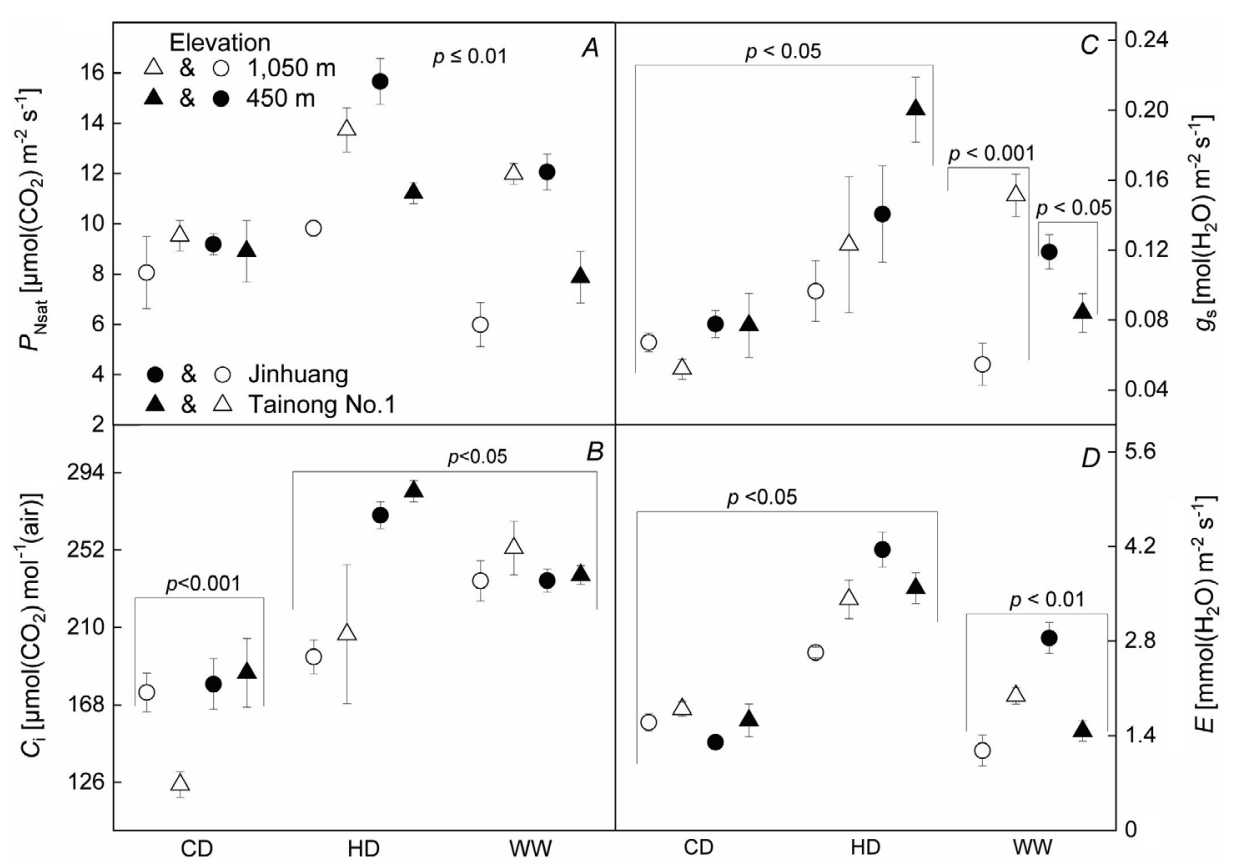

Fig. 6. Mean ( \pm SE) seasonal light-saturated photosynthetic rate $\left(P_{\text {Nsat }}\right)(A)$; intercellular $\mathrm{CO}_{2}$ concentration $\left(C_{\mathrm{i}}\right)(B)$; stomatal conductance $\left(g_{\mathrm{s}}\right)(C)$; and transpiration rate $(E)(D)$ of mango cultivars Tainong No. 1 and Jinhuang grown at $1,050 \mathrm{~m}$ and $450 \mathrm{~m}$ during colddry (CD), hot-dry (HD), and warm-wet (WW) seasons.
Seasonal light-saturated photosynthesis $\left(P_{\text {Nsat }}\right)$ of cultivar Tainong No. 1 was higher at $1,050 \mathrm{~m}$, while this was true for cultivar Jinhuang at $450 \mathrm{~m}$ during hot-dry and wet-warm seasons. The $1,050 \mathrm{~m}$ elevation had lower temperatures compared to the $450 \mathrm{~m}$ elevation (Fig. 1A). This signified that cultivar Tainong No. 1 performed better in cooler climates, while Jinhuang performed better in warmer climatic conditions, which was also reported by Elsheery et al. (2007). Studies have also shown both decreases (Kao and Chang 2001, Zhang et al. 2005, Mujawamariya et al. 2018) and increases (Friend et al. 1989, Premoli and Brewer 2007, Mujawamariya et al. $2018)$ in $P_{\text {Nsat }}$ with elevation depending on elevation and plant species studied.

Stomatal conductance $\left(g_{\mathrm{s}}\right)$ differed across elevations during the hot-dry season along with transpiration rate $(E)$ during hot-dry and warm-wet seasons between studied mango cultivars. Additionally, $g_{\mathrm{s}}$ and $E$ were generally low during cold-dry at both elevations and no difference was observed between cultivars. Previous studies on tropical plants have shown that $g_{\text {s }}$ and $E$ typically decrease with an increasing elevation, which is typically attributed to the decrease in temperature and vapor pressure deficit (VPD) with elevation (Sendall et al. 2009, Motzer et al. 2017, Mujawamariya et al. 2018). Furthermore, $C_{\mathrm{i}}$ was generally consistent between cultivars at both elevations. Comparable results of seasonal fluctuation in $C_{\mathrm{i}}$ have also been reported by Munjonji et al. (2021).

Studies have established that mangoes grow well in hot and dry climates; however, photosynthetic performance depends on cultivar and location of growth (Allen et al. 2000, Allen and Ort 2001, Elsheery et al. 2007, Elsheery and Cao 2008, Damour et al. 2009, Lu et al. 2012). Furthermore, physiological responses of mango cultivars to the environment are related to the evolutionary center of origin of cultivars (Morton 1987, Whiley 1993). Thus, variation in the photosynthesis performances, $g_{\mathrm{s}}$, and $E$ of the two cultivars could also be due to their adaptation to climatic conditions of their respective growing areas. In this case, cultivar Tainong No. 1 is predominantly grown in the dry subtropics featuring hot summers and cooler winters. Cultivar Jinhuang, however, is grown in continuously hot humid tropics (Mukherjee 1972, Gao et al. 2011). Jinhuang, a polyembryonic cultivar, suffers more from the low temperature at $1,050 \mathrm{~m}$ than cultivar Tainong No. 1, resulting in a reduction of photosynthetic performance at $1,050 \mathrm{~m}$, cooler location, which was also observed by Elsheery et al. (2007, 2008).

Furthermore, we found a strong positive correlation between photosynthetic capacity parameters including $P_{\mathrm{N}}, J_{\max }$, carboxylation, and AQE with leaf nitrogen per area $\left(\mathrm{N}_{\mathrm{a}}\right)$. Studies have demonstrated that nitrogen is the macronutrient with the strongest direct relationship with photosynthesis in plants (Urban et al. 2006, Kattge et al. 2009, Zhang et al. 2017). Nitrogen application can enhance associated enzyme activities, thereby increasing the photosynthetic capacity of leaves (Shangguan et al. 2000, Pal et al. 2005, Li et al. 2013b). In contrast, photosynthetic capacity can be reduced at lower nitrogen concentrations (Pal et al. 2005, Li et al. 2013b). Moreover, nitrogen affects plant photosynthetic efficiency by affecting the maximum net photosynthetic rate and other associated parameters (Urban et al. 2006, Kattge et al. 2009). Previous studies have revealed that optimal nitrogen availability highly influences leaf $P_{\mathrm{N}}, J_{\max }$, carboxylation, and AQE (Evans 1989, Cordell et al. 1999, Shi et al. 2006, Bote et al. 2018, Wang et al. 2018, Fei et al. 2019). Moreover, studies on mango and other tree species have also reported that leaf nitrogen content and partitioning both exert direct impacts on photosynthetic capacity (Körner 1989, Kenzo et al. 2006, Urban et al. 2006, Kositsup et al. 2010, Domingues et al. 2014, Xu et al. 2015). 
The variations in leaf nitrogen per area $\left(\mathrm{N}_{\mathrm{a}}\right)$ observed in Fig. 6 resulted from the effect of elevation on the leaf total nitrogen $\left(\mathrm{N}_{\mathrm{m}}\right)$ contents of Tainon No. 1 and Jinhuang (Fig. 5). Previous studies on field-grown plants have also repeatedly reported that leaf nitrogen content varies across ecological gradients associated with elevation (Morecroft and Woodward 1996, Macek et al. 2012, He et al. 2016, Ram et al. 2020). This variation due to elevation has principally been attributed to exposure to low temperatures (Morecroft and Woodward 1996, Soethe et al. 2008, He et al. 2016, Du et al. 2017). Furthermore, plants grown at low temperatures in laboratory conditions also showed higher leaf nitrogen (Sun et al. 2011). The higher leaf nitrogen of mango leaves at higher elevation could be present to maintain photosynthetic efficiency in constraining environmental conditions as also reported in other tree species (Körner 1989, Liu et al. 2012).

This study was limited to examining photosynthesis and seasonal gas exchange of two mango cultivars before first flowering and fruiting. We suggest that assessing the effects of elevation on photosynthesis and associated traits in other commercial mango cultivars during the time of flowering and fruit production could add value to our findings. Nevertheless, our study demonstrated that elevation influences photosynthesis performance and seasonal gas exchange of two primary commercial cultivars. This suggests that shifting mango plantations to higher elevations should consider selecting specific cultivars for environmental suitability.

\section{References}

Allen D.J., Ort D.R.: Impacts of chilling temperatures on photosynthesis in warm-climate plants. - Trends Plant Sci. 6: 36-42, 2001.

Allen D.J., Ratner K., Giller Y.E. et al.: An overnight chill induces a delayed inhibition of photosynthesis at midday in mango (Mangifera indica L.). - J. Exp. Bot. 51: 1893-1902, 2000.

Bote A.D., Zana Z., Ocho F.L., Vos J.: Analysis of coffee (Coffea arabica L.) performance in relation to radiation level and rate of nitrogen supply. II. Uptake and distribution of nitrogen, leaf photosynthesis and first bean yields. - Eur. J. Agron. 92: 107-114, 2018

Cordell S., Goldstein G., Meinzer F.C., Handley L.L.: Allocation of nitrogen and carbon in leaves of Metrosideros polymorpha regulates carboxylation capacity and ${ }^{813} \mathrm{C}$ along an altitudinal gradient. - Funct. Ecol. 13: 811-818, 1999.

Damour G., Vandame M., Urban L.: Long-term drought results in a reversible decline in photosynthetic capacity in mango leaves, not just a decrease in stomatal conductance. - Tree Physiol. 29: 675-684, 2009.

Domingues T.F., Martinelli L.A., Ehleringer J.R.: Seasonal patterns of leaf-level photosynthetic gas exchange in an eastern Amazonian rain forest. - Plant Ecol. Divers. 7: 189203, 2014.

Du B., Ji H., Peng C. et al.: Altitudinal patterns of leaf stoichiometry and nutrient resorption in Quercus variabilis in the Baotianman Mountains, China. - Plant Soil 413: 193-202, 2017.

Dusenge M.E., Wallin G., Gårdesten J. et al.: Photosynthetic capacity of tropical montane tree species in relation to leaf nutrients, successional strategy and growth temperature. -
Oecologia 177: 1183-1194, 2015.

Ehleringer J., Björkman O.: Quantum yields for $\mathrm{CO}_{2}$ uptake in $\mathrm{C}_{3}$ and $\mathrm{C}_{4}$ plants: dependence on temperature, $\mathrm{CO}_{2}$, and $\mathrm{O}_{2}$ concentration. - Plant Physiol. 59: 86-90, 1977.

Ehleringer J., Pearcy R.W.: Variation in quantum yield for $\mathrm{CO}_{2}$ uptake among $\mathrm{C}_{3}$ and $\mathrm{C}_{4}$ plants. - Plant Physiol. 73: 555-559, 1983.

Elsheery N.I., Cao K.-F.: Gas exchange, chlorophyll fluorescence, and osmotic adjustment in two mango cultivars under drought stress. - Acta Physiol. Plant. 30: 769-777, 2008.

Elsheery N.I., Wilske B., Cao K.-F.: The effect of night chilling on gas exchange and chlorophyll fluorescence of two mango cultivars growing under two irradiances. - Acta Bot. Yunnan. 30: 447-456, 2008.

Elsheery N.I., Wilske B., Zhang J.-L., Cao K.-F.: Seasonal variations in gas exchange and chlorophyll fluorescence in the leaves of five mango cultivars in southern Yunnan, China. J. Hortic. Sci. Biotech. 82: 855-862, 2007.

Evans J.R.: Photosynthesis and nitrogen relationships in leaves of $\mathrm{C}_{3}$ plants. - Oecologia 78: 9-19, 1989.

FAO: Mango: Post-Harvest Operations. Post-Harvest Compendium. Pp. 70. FAO, 2002.

FAO: Major tropical fruits: Preliminary market results 2019. Pp. 24. FAO, Rome 2020.

Fei C., Su J.X., Li Y.Y. et al.: Light-response characteristics of photosynthesis of drip-irrigated sugar beet under different nitrogen fertilizer managements. - Photosynthetica 57: 804$811,2019$.

Friend A.D., Woodward F.I., Switsur V.R.: Field measurements of photosynthesis, stomatal conductance, leaf nitrogen and ${ }^{813} \mathrm{C}$ along altitudinal gradients in Scotland. - Funct. Ecol. 3: 117-122, 1989.

Fujimura S., Shi P., Iwama K. et al.: Effect of altitude on the response of net photosynthetic rate to carbon dioxide increase by spring wheat. - Plant Prod. Sci. 13: 141-149, 2010.

Gale J.: Plants and altitude - revisited. - Ann. Bot.-London 94: 199,2004

Gao A., Chen Y., Crane J.H. et al.: Status and analysis on mango production in China. - In: Advances in Biomedical Engineering: Proceedings of 2011 International Conference on Agricultural and Biosystems Engineering. Pp. 472-476, 2011.

Gao A., Chen Y., Luo R. et al.: Development status of Chinese mango industry in 2018. - Adv. Agric. Hortic. Entomol. 2019: $1-6,2019$.

He X., Hou E., Liu Y., Wen D.: Altitudinal patterns and controls of plant and soil nutrient concentrations and stoichiometry in subtropical China. - Sci. Rep.-UK 6: 24261, 2016.

Jung S., Steffen K.L., Lee H.J.: Comparative photoinhibition of a high and a low altitude ecotype of tomato (Lycopersicon hirsutum) to chilling stress under high and low light conditions. - Plant Sci. 134: 69-77, 1998.

Kao W.-Y., Chang K.-W.: Altitudinal trends in photosynthetic rate and leaf characteristics of Miscanthus populations from central Taiwan. - Aust. J. Bot. 49: 509-514, 2001.

Kattge J., Knorr W., Raddatz T., Wirth C.: Quantifying photosynthetic capacity and its relationship to leaf nitrogen content for global-scale terrestrial biosphere models. - Glob. Change Biol. 15: 976-991, 2009

Kenzo T., Ichie T., Watanabe Y. et al.: Changes in photosynthesis and leaf characteristics with tree height in five dipterocarp species in a tropical rain forest. - Tree Physiol. 26: 865-873, 2006.

Kingston-Smith A.H., Harbinson J., Williams J., Foyer C.H.: Effect of chilling on carbon assimilation, enzyme activation, and photosynthetic electron transport in the absence of 
photoinhibition in maize leaves. - Plant Physiol. 114: 10391046, 1997.

Körner C.: The nutritional status of plants from high altitudes: A worldwide comparison. - Oecologia 81: 379-391, 1989.

Körner C.: The use of 'altitude' in ecological research. - Trends Ecol. Evol. 22: 569-574, 2007.

Kositsup B., Kasemsap P., Thanisawanyangkura S. et al.: Effect of leaf age and position on light-saturated $\mathrm{CO}_{2}$ assimilation rate, photosynthetic capacity, and stomatal conductance in rubber trees. - Photosynthetica 48: 67-78, 2010.

Laisk A., Oja V., Rasulov B. et al.: Quantum yields and rate constants of photochemical and nonphotochemical excitation quenching: Experiment and model. - Plant Physiol. 115: 803-815, 1997.

Li D., Tian M., Cai J. et al.: Effects of low nitrogen supply on relationships between photosynthesis and nitrogen status at different leaf position in wheat seedlings. - Plant Growth Regul. 70: 257-263, 2013b.

Li L., Wang S.B., Chen J.Z. et al.: Characterizations of major antioxidants at harvest-maturity and edible-ripening stages of three mango (Mangifera indica L.) cultivars. - Acta Hortic. 992: 529-536, $2013 \mathrm{a}$.

Liu J., Zhang D., Zhou G., Duan H.: Changes in leaf nutrient traits and photosynthesis of four tree species: Effects of elevated $\left[\mathrm{CO}_{2}\right], \mathrm{N}$ fertilization and canopy positions. - J. Plant Ecol. 5: 376-390, 2012.

Lu P., Chacko E.K., Bithell S.L. et al.: Photosynthesis and stomatal conductance of five mango cultivars in the seasonally wet-dry tropics of northern Australia. - Sci. Hortic.-Amsterdam 138: 108-119, 2012.

Luo C., He X.H., Chen H. et al.: Genetic relationship and diversity of Mangifera indica L.: revealed through SCoT analysis. - Genet. Resour. Crop Ev. 59: 1505-1515, 2012.

Luvaha E., Netondo G.W., Ouma G.: Physiological responses of mango (Mangifera indica) rootstock seedlings to water stress. - J. Agric. Biol. Sci. 2: 6-12, 2007.

Luvaha E., Netondo G.W., Ouma G.: Effect of water deficit on the physiological and morphological characteristics of mango (Mangifera indica) rootstock seedlings. - Am. J. Plant Physiol. 3: 1-15, 2008.

Macek P., Klimeš L., Adamec L. et al.: Plant nutrient content does not simply increase with elevation under the extreme environmental conditions of Ladakh, NW Himalaya. - Arct. Antarct. Alp. Res. 44: 62-66, 2012.

Marshall B., Biscoe P.V.: A model for $\mathrm{C}_{3}$ leaves describing the dependence of net photosynthesis on irradiance: II. Application to the analysis of flag leaf photosynthesis. J. Exp. Bot. 31: 41-48, 1980.

Mathur P.N., Ramirez-Villegas J., Jarvis A.: The impact of climate change on tropical and subtropical horticultural production. - In: Sthapit B., Rao V.R., Sthapit S. (ed.): Tropical Fruit Tree Species and Climate Change. Pp. 27-44. Bioversity International, New Delhi 2012.

Mng'omba S.A., Akinnifesi F.K., Sileshi G., Ajayi C.O.: Rootstock growth and development for increased graft success of mango (Mangifera indica) in the nursery. - Afr. J. Biotechnol. 9: 1317-1324, 2010.

Morecroft M.D., Woodward F.I.: Experiments on the causes of altitudinal differences in the leaf nutrient contents, size and $\delta^{13} \mathrm{C}$ of Alchemilla alpina. - New Phytol. 134: 471-479, 1996.

Morton J.F.: Mango. - In: Morton J.F.: Fruits of Warm Climates. Pp. 221-239. Echo Point Books \& Media, Miami 1987.

Motzer T., Munz N., Küppers M. et al.: Stomatal conductance, transpiration and sap flow of tropical montane rain forest trees in the southern Ecuadorian Andes. - Tree Physiol. 25: 1283$1293,2017$.
Mujawamariya M., Manishimwe A., Ntirugulirwa B. et al.: Climate sensitivity of tropical trees along an elevation gradient in Rwanda. - Forests 9: 647, 2018.

Mukherjee S.K.: Origin of mango (Mangifera indica). - Econ. Bot. 26: 260-264, 1972.

Munjonji L., Ayisi K.K., Mafeo T.P. et al:: Seasonal variation in soil $\mathrm{CO}_{2}$ emission and leaf gas exchange of well-managed commercial Citrus sinensis (L.) orchards. - Plant Soil 465: 65-81, 2021.

Normand F., Lauri P.-E., Legave J.-M.: Climate change and its probable effects on mango production and cultivation. - Acta Hortic. 1075: 21-32, 2015.

Oberhuber W., Dai Z.-Y., Edwards G.E.: Light dependence of quantum yields of Photosystem II and $\mathrm{CO}_{2}$ fixation in $\mathrm{C}_{3}$ and $\mathrm{C}_{4}$ plants. - Photosynth. Res. 35: 265-274, 1993.

Pal M., Rao L.S., Jain V. et al.: Effects of elevated $\mathrm{CO}_{2}$ and nitrogen on wheat growth and photosynthesis. - Biol. Plantarum 49: 467-470, 2005.

Pinto A.C.D.Q., Saúco V.G., Mitra S.K., Ferreira F.R.: Mango propagation. - Rev. Bras. Frutic. 40: e-586, 2018.

Premoli A.C., Brewer C.A.: Environmental v. genetically driven variation in ecophysiological traits of Nothofagus pumilio from contrasting elevations. - Aust. J. Bot. 55: 585-591, 2007.

Rajan S.: Phenological responses to temperature and rainfall: A case study of mango. - In: Sthapit B., Rao V.R., Sthapit S. (ed.): Tropical Fruit Tree Species and Climate Change. Pp. 71-96. Bioversity International, New Delhi 2011.

Ram R.A., Rahim M.A., Alam M.S.: Diagnosis and management of nutrient constraints in mango. - In: Srivastava A.K., Hu C. (ed.): Fruit Crops: Diagnosis and Management of Nutrient Constraints. Pp. 629-650. Elsevier, Amsterdam 2020.

Sakata T., Yokoi Y.: Analysis of the $\mathrm{O}_{2}$ dependency in leaflevel photosynthesis of two Reynoutria japonica populations growing at different altitudes. - Plant Cell Environ. 25: 65-74, 2002.

Sendall K.M., Vourlitis G.L., Lobo F.A.: Seasonal variation in the maximum rate of leaf gas exchange of canopy and understory tree species in an Amazonian semi-deciduous forest. - Braz. J. Plant Physiol. 21: 65-74, 2009.

Shangguan Z., Shao M., Dyckmans J.: Effects of nitrogen nutrition and water deficit on net photosynthetic rate and chlorophyll fluorescence in winter wheat. - J. Plant Physiol. 156: 46-51, 2000.

Sharkey T.D., Bernacchi C.J., Farquhar G.D., Singsaas E.L.: Fitting photosynthetic carbon dioxide response curves for $\mathrm{C}_{3}$ leaves. - Plant Cell Environ. 30: 1035-1040, 2007.

Shi Z., Liu S., Liu X., Centritto M.: Altitudinal variation in photosynthetic capacity, diffusional conductance and ${ }^{813} \mathrm{C}$ of butterfly bush (Buddleja davidii) plants growing at high elevations. - Physiol. Plantarum 128: 722-731, 2006.

Soethe N., Lehmann J., Engels C.: Nutrient availability at different altitudes in a tropical montane forest in Ecuador. J. Trop. Ecol. 24: 397-406, 2008.

Sun S.Q., Wu Y.H., Zhou J. et al.: Comparison of element concentrations in fir and rhododendron leaves and twigs along an altitudinal gradient. - Environ. Toxicol. Chem. 30: 26082619, 2011.

Urban L., Montpied P., Normand F.: Season effects on leaf nitrogen partitioning and photosynthetic water use efficiency in mango. - J. Plant Physiol. 163: 48-57, 2006.

Vats S.K., Kumar S.: Photosynthetic response of Podophyllum hexandrum Royle from different altitudes in Himalayan ranges. - Photosynthetica 44: 136-139, 2006.

Wang J., Wen X., Zhang X. et al.: Co-regulation of photosynthetic capacity by nitrogen, phosphorus and magnesium in a subtropical Karst forest in China. - Sci. Rep.-UK 8: 7406, 2018. 
Wang M., Ying D., Wang Q. et al.: Genetic diversity analysis and fingerprinting construction of mango cultivars in China.J. South. Agric. 46: 1154-1159, 2015.

Whiley A.W.: Environmental effects on phenology and physiology of mango - a review. - Acta Hortic. 341: 168-176, 1993.

Whiley A.W., Rasmussen T.S., Saranah J.B., Wolstenholme B.N.: Effect of temperature on growth, dry matter production and starch accumulation in ten mango (Mangifera indica L.) cultivars. - J. Hortic. Sci. 64: 753-765, 1989.

Wittich B., Horna V., Homeier J., Leuschner C.: Altitudinal change in the photosynthetic capacity of tropical trees: A case study from Ecuador and a pantropical literature analysis. Ecosystems 15: 958-973, 2012.
Xu J., Wang Y., Yang S. et al.: Improved performance of photosynthetic light response equations with unified parameters for rice leaves with different SPAD values. - Pak. J. Bot. 47: 877-882, 2015.

Zhang S.B., Yin L.X.: Plasticity in photosynthesis and functional leaf traits of Meconopsis horridula var. racemosa in response to growth irradiance. - Bot. Stud. 53: 335-343, 2012.

Zhang S.-B., Zhou Z.-K., Hu H. et al.: Photosynthetic performances of Quercus pannosa vary with altitude in the Hengduan Mountains, southwest China. - Forest Ecol. Manag. 212: 291-301, 2005.

Zhang Y.Q., Wang J.D., Gong S.H. et al.: Nitrogen fertigation effect on photosynthesis, grain yield and water use efficiency of winter wheat. - Agr. Water Manage. 179: 277-287, 2017.

(C) The authors. This is an open access article distributed under the terms of the Creative Commons BY-NC-ND Licence. 